\title{
Study Site Status Code
}

National Cancer Institute

\section{Source}

National Cancer Institute. Study Site Status Code. NCI Thesaurus. Code C94292.

A coded value specifying the phase in the lifecycle of the study site. 